\title{
THE DIAMOND-BEARING MIR ECLOGITES, YAKUTIA: Nd AND Sr ISOTOPIC EVIDENCE FOR CONTINENTAL CRUSTAL INPUT IN AN ARCHEAN OCEANIC ENVIRONMENT
}

\author{
Snyder, G.A. 1, Taylor, L.A. 1, Beard, B.L. 1,2, Halliday, A.N. ${ }^{3}$, \& Sobolev, N.V. 4 \\ 1. Planetary Geosciences Institute, Department of Geological Sciences, University of Tennessee, \\ Knoxville, TN 37996-1410 \\ 2. Department of Geology and Geophysics, University of Wisconsin, Madison, WI 53706 \\ 3. Department of Geological Sciences, University of Michigan, Ann Arbor, MI 48109 \\ 4. Russian Academy of Sciences, Novosibirsk, Russia
}

\section{Introduction}

There is a consensus building that most "mantle" eclogite xenoliths are fragments of subducted oceanic crust which may have lost a partial melt during high-pressure fusion (e.g., MacGregor and Manton, 1986; Shervais et al., 1988, Jacob et al., 1994; Ireland et al., 1994). The old ages suggested from radiogenic isotopic studies of these xenoliths (e.g., Pearson et al., 1995) also make them some of our best evidence of subduction operating during the Archean.

Our previous isotopic work on Yakutian eclogites, specifically from the Udachnaya kimberlite, showed a dearth of typical crustal signatures (e.g., Snyder et al., 1997). Our observations have not been fully accepted by some and have engendered some debate (Jacob et al., 1998; Snyder et al., 1998). Ireland et al. (1994) even questioned the use of trace-element and radiogenic isotopic studies in eclogites as a tool for gaining information about their genesis. However, oxygen isotopic studies of eclogites from the Mir kimberlite showed signficant correlations with mineral chemistry (including trace-elements) and led to their interpretation as samples from a dismembered proto-ophiolite (Beard et al., 1996). Thus, a thorough radiogenic isotopic study of the Mir eclogites, in conjunction with previous isotopic studies, may allow us to understand the effect of subduction, metamorphism, and metasomatism on radiogenic isotopes and assess their usefulness in the study and interpretation of eclogite petrogenesis.

Isotopic Variations and Correlations with Mineral Chemistry

We have compiled all oxygen and $\mathrm{CaO}$ data on Yakutian eclogitic garnets in Figure 1 (dashed line connects the well-characterized Mir eclogites). These data show a distinct trend with decreasing $\mathrm{CaO}$ abundance in the garnet (Beard et al., 1996). This trend begins with a cluster of values at the highest $\mathrm{CaO}$ and among the lowest $\delta^{18} \mathrm{O}$ values of any of the Yakutian eclogites (Fig. 1: squares $=$ Mir, stars and diamonds $=$ Udachnaya). From just below this cluster (at approximately $9 \mathrm{wt} \% \mathrm{CaO}$ in garnet, the curve of data loops back to lower $\delta^{18} \mathrm{O}$ values with decreasing $\mathrm{CaO}$. At samples $\mathrm{M}-60$, M-180 and U-281 (approximately 5-

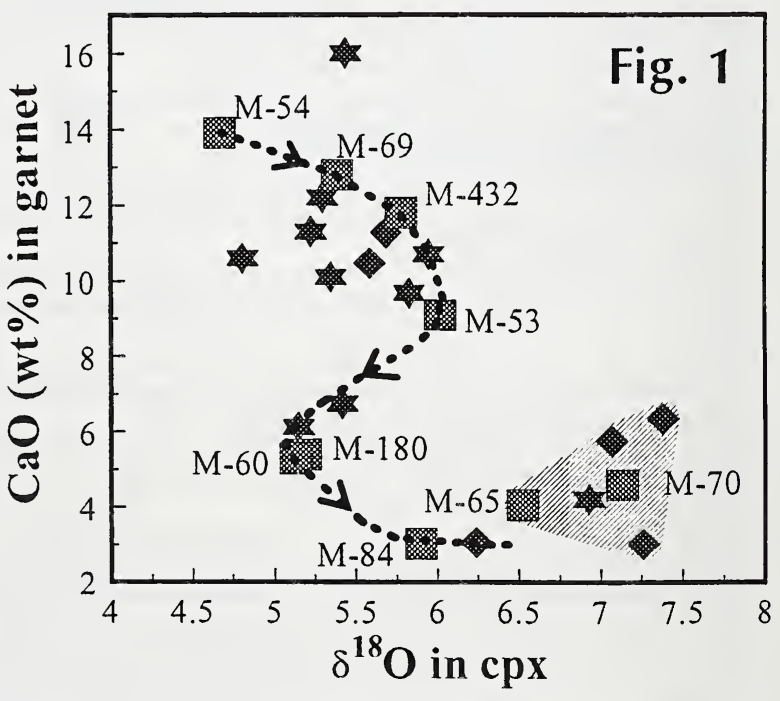
$6 \mathrm{wt} \% \mathrm{CaO}$ ), the curve of data projects to progressively higher $\delta^{18} \mathrm{O}$ values, until, at $6.3 \%$, the values appear to scatter again to higher $\mathrm{CaO}$ with increasing $\delta^{18} \mathrm{O}$. Those samples that deviate 
from this array at higher $\delta^{18} \mathrm{O}$, have elevated ${ }^{87} \mathrm{Sr} /{ }^{86} \mathrm{Sr}$ and $\varepsilon_{\mathrm{Nd}}$ values, that are similar to upper continental crust or kimberlite at $362 \mathrm{Ma}$. Thus, the isotopic variations in these samples may be due to either contamination by kimberlite or continental crustal input into the oceanic protolith.

Due to the low $\mathrm{Rb} / \mathrm{Sr}$ ratios of these (reconstructed) eclogites, the measured ${ }^{87} \mathrm{Sr} /{ }^{86} \mathrm{Sr}$ values are presumed to be near those of the original protolith, even though the protolith may be in excess of $2 \mathrm{Ga}$ old. Therefore, a plot of ${ }^{87} \mathrm{Sr} /{ }^{86} \mathrm{Sr}$ versus $\delta^{18} \mathrm{O}$ (Fig. 2) is likely to be diagnostic of igneous processes in the protolith. The combined data for Yakutian eclogites show two distinct

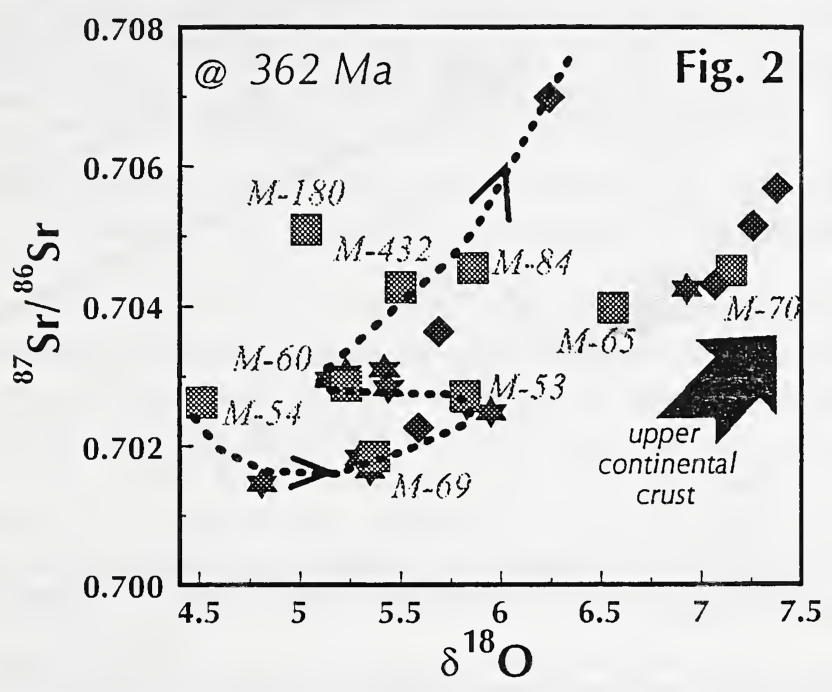

groups (e.g., Fig. 2). These two groups suggest that either a) many of the high $\delta^{18} \mathrm{O}$, high ${ }^{87} \mathrm{Sr} /{ }^{86} \mathrm{Sr}$ eclogites have been affected by kimberlitic metasomatism (also, see above), or b) if a subducted crustal origin is assumed, two separate petrogenetic pathways must be envisioned for the evolution of those rocks. One pathway, which includes the low-Ca Mir eclogites, follows a well-defined trend of increasing $\delta^{18} \mathrm{O}(+4.7$ to $+7.4 \%$ ) with slightly increasing $\mathrm{Sm} / \mathrm{Nd}, \varepsilon_{\mathrm{Nd}},(+1.6$ to $+3.0 @ 362 \mathrm{Ma}$ ), and ${ }^{87} \mathrm{Sr} / 87 \mathrm{Sr}$ (Fig. 2). A second dominant trend includes the high-Ca Mir eclogites. This trend is more diffuse, exhibits large increases in $\mathrm{Sm} / \mathrm{Nd}$ and $\varepsilon_{\mathrm{Nd}}(+4.7$ to +17$)$, and exhibits a complex array of decreasing $\mathrm{Ca}$ (dashed line in Fig. 2) and increasing $\delta^{18} \mathrm{O}$. Furthermore, $\delta^{18} \mathrm{O}$ in this trend does not exceed $6.2 \%$. These two trends likely represent two distinct environments of formation for Yakutian eclogites: a shallow oceanic crustal environment with higher $\delta^{18} \mathrm{O}$ values, exhibiting a significant continental, terrigenous sediment input (as evidenced by large variations in ${ }^{87} \mathrm{Sr} /{ }^{86} \mathrm{Sr}$ and lower $\varepsilon_{\mathrm{Nd}}$ values), and a deeper oceanic crustal environment with lower $\delta^{18} \mathrm{O}$ and shielded from continental crustal sediment input.

In contrast to previous studies on southern African and Yakutian eclogites, none of the Mir eclogites indicate an ultra-depleted mantle reservoir (e.g., $\varepsilon_{\mathrm{Nd}}$ values up to +250 ).

\section{Discussion}

Although the age of the Mir kimberlite is fairly well-known (361.5 Ma; Davis et al., 1980), the age of the sources or protoliths for the eclogites are not definitive. The low ${ }^{87} \mathrm{Sr} /{ }^{86} \mathrm{Sr}$ ratios of most of the eclogites suggest an old, middle to early Precambrian source, possibly coeval with the Udachnaya eclogites (2.9 Ga, Pearson et al., 1995). However, the $\mathrm{Nd}$ isotopic evolution diagram (Fig. 3: CHUR = chondritic uniform reservoir or Bulk Earth, DM = depleted mantle) for these eclogites is quite different than that for the Udachnaya eclogites. Whereas Nd isotopic evolutionary lines for the Udachnaya eclogites did not begin to converge at unique sources until $>2 \mathrm{Ga}$, the Mir eclogites seem to converge prior to this time. All but one Mir eclogite (M-54) intersect CHUR and depleted mantle reservoirs prior to $2.0 \mathrm{Ga}$. Three of the eclogites (M-53, M-69, and M-70) converge (box B in Fig. 3) at 1.1 Ga near chondritic mantle (CHUR) and three others (M-60, M-84, and M-180) converge (box A in Fig. 3) at 1.2 Ga near depleted mantle. Although these convergeraes could be fortuitous, and there are signficant errors 
involved in the whole-rock reconstructions, they would seem to suggest that the isotopic composition of these six eclogites were derived from depleted mantle and/or undepleted mantle reservoirs after at most 2.0 Ga ago. This is an interesting observation as the Mir kimberlite is closer to the edge of the Siberian craton and, thereoritically, could have tapped an oceanic crustal source at depth that was subducted and added to the sub-cratonic lithosphere at a later time than that for eclogites from the more centrally located Udachnaya kimberlite.

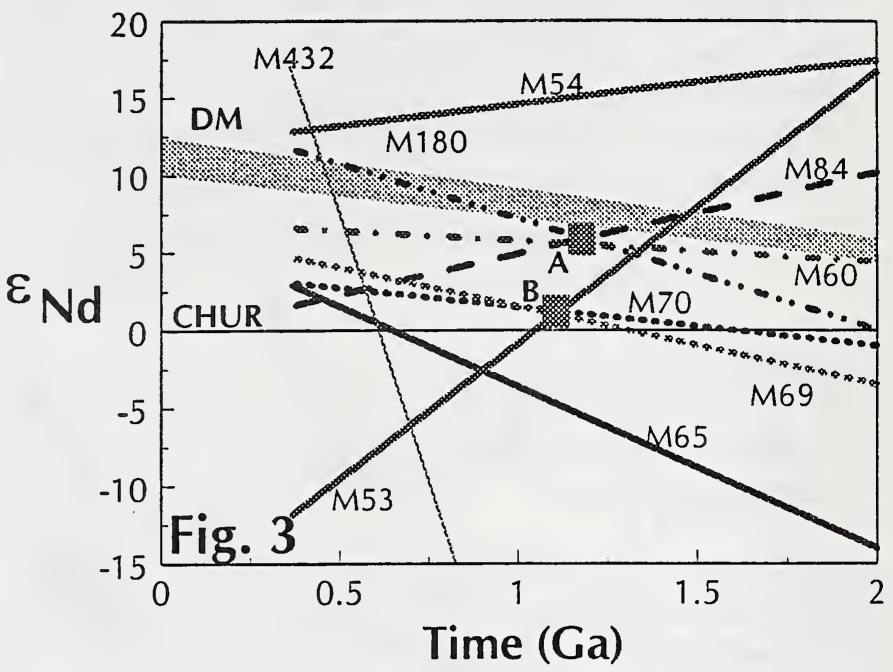

\section{References}

Beard, B.L., Fraracci, K.N., Taylor, L.A., Snyder, G.A., Clayton, R.N., Mayeda, T.K., and Sobolev, N.V., 1996, Petrography and geochemistry of eclogites from the Mir kimberlite, Yakutia, Russia: Contributions to Mineralogy and Petrology 125, 293-310.

Davis, G.L., Sobolev, N.V., and Khar'kiv, A.D., 1980, New data on the age of Yakutian kimberlites obtained by the uranium-lead method on zircons: Doklady Akadameii Nauk SSSR 254, 175-179.

Ireland, T.R., Rudnick, R.L., and Spetsius, Z.V., 1994, Trace elements in diamond inclusions from eclogites reveal a link to Archean granites: Earth and Planetary Science Letters 128, 199-213.

Jacob, D., Jagoutz, E., Lowry, D., Mattey, D., and Kudrjavtseva, G., 1994, Diamondiferous eclogites from Siberia: remnants of Archean oceanic crust: Geochimica et Cosmochimica Acta 58, 5191-5207.

Jacob, D., Jagoutz, E., Lowry, D., and Zinngrebe, E., 1998, Comment on "The origins of Yakutian eclogite xenoliths" by G.A. Snyder, L.A. Taylor, G. Crozaz, A.N. Halliday, B.L. Beard, V.N. Sobolev, and N.V. Sobolev: Journal of Petrology 39, in press.

MacGregor, I.D. and Manton, W.I., 1986, Roberts Victor eclogites: ancient oceanic crust: Journal of Geophysical Research 91, 14063-14079.

Pearson, D.G., Snyder, G.A., Shirey, S.B., Taylor, L.A., Carlson, R.W., and Sobolev, N.V., 1995, Re-Os isotope evidence for a mid-Archean age of diamondiferous eclogite xenoliths from Siberia and constraints on Archean tectonics: Nature 374, 711-713.

Shervais, J.W., Taylor, L.A., Lugmair, G.W., Clayton, R.N., Mayeda, T.K., and Korotev, R.L., 1988, Early Proterozoic oceanic crust and the evolution of subcontinental mantle: eclogites and related rocks from southern Africa: Geological Society of America Bulletin 100, 411-423.

Snyder, G.A., Taylor, L.A., Crozaz, G., Halliday, A.N., Beard, B.L., Sobolev, V.N., and Sobolev, N.V., 1997, The origins of Yakutian eclogite xenoliths: Journal of Petrology 38, 85-113.

Snyder, G.A., Taylor, L.A., Beard, B.L., Crozaz, G., Halliday, A.N., Sobolev, V.N., and Sobolev, N.V., 1998, Reply to a comment by D. Jacob et al. on "The origins of Yakutian eclogite xenoliths": Journal of. Petrology 39 , in press. 